\section{Inheritance of Resistance to the Watermelon Strain of Papaya Ringspot Virus in the Cucumber Line TMG-1}

\author{
T. Wai ${ }^{1}$ and R. Grumet ${ }^{2}$ \\ Department of Horticulture, Michigan State University, East Lansing, \\ MI 48824
}

Additional index words. plant virus resistance, watermelon mosaic virus, potyvirus, Cucumis sativus

\begin{abstract}
The inbred cucumber (Cucumis sativus L.) line TMG-1 is resistant to three potyviruses: zucchini yellow mosaic virus (ZYMV), watermelon mosaic virus (WMV), and the watermelon strain of papaya ringspot virus (PRSV-W). In this study we sought to determine the genetics of resistance to PRSV-W. TMG-1 was crossed with WI-2757, an inbred line susceptible to all three viruses. Segregation data indicated that resistance to PRSV-W was due to a single dominant gene (proposed designation, Prsv-2). Enzymelinked immunosorbent assay (ELISA) data suggested that the mechanism of resistance to PRSV-W differs from that for ZYMV and WMV, and may be better described as tolerance. Although the plants were free of symptoms, high PRSV-W titers existed in young expanding leaves of the TMG-1 plants and the WI-2757 x TMG-1 $F_{1}$ progeny.
\end{abstract}

The watermelon strain of papaya ringspot virus (PRSV-W), formerly known as watermelon mosaic virus-1 (WMV-1), is one of several potyviruses that can cause severe yield losses in cucurbit crops (Davis and Mizuki, 1985; Nameth et al., 1985, 1986; Purcifull and Gonsalves, 1984; Sammons et al., 1989). Other economically important cucurbit potyviruses include zucchini yellow mosaic virus (ZYMV) and watermelon mosaic virus (WMV). In an effort toidentify sources of resistance toZYMV in cucumber, Provvidenti (1985) identified a single plant selection from the Chinese line Taichung Mou Gua (TMG-1) that was resistant to three potyviruses: ZYMV, WMV, and PRSV-W. The resistance to ZYMV was conferred by a single recessive gene (Provvidenti, 1987). The inheritance of resistance to PRSV-W, however, was not characterized. There are a few reports of PRSV-W resistance in cucumber germplasm, but in only one case, for the cultivar Surinam Local, has the genetics of resistance been determined (Wang et al.,

Received for publication 2 May 1994. Accepted for publication 29 Dec. 1994. We thank Jack Staub for helpful advice and for generously providing the TMG-1 and WI-2757 seed and the initial supplies of $\mathrm{F}_{1}, \mathrm{~F}_{2}$, and $\mathrm{BC}$ progeny. We also thank James Kelly and James Hancock for helpful reviews of the manuscript. This work was in part supported by the Office of U.S. Agency for International Development/Cairo/ Agr/A under Cooperative Agreement 263-0152-A00-3036-00; by a Patricia Harris Graduate Fellowship to T.W.; and by the Michigan Agricultural Experiment Station. The cost of publishing this paper was defrayed in part by the payment of page charges. Under postal regulations, this paper therefore must be hereby marked advertisement solely to indicate this fact.

${ }^{1}$ Current address: Molecular Plant Pathology Laboratory, Plant Science Institute, U.S. Dept. of Agriculture, Agricultural Research Service, Beltsville Agricultural Research Center-West, Beltsville, MD 20705.

${ }^{2}$ To whom reprint requests should be addressed.
1984). Resistance in that genotype was conferred by a single recessive gene, prsv (originally named $w m v-1-1$, Wang et al., 1984; renamed prsv, Wehner, 1993). In this work we sought to characterize the inheritance of resistance to PRSV-W in TMG-1.

\section{Materials and Methods}

Maintenance of virus inocula. ZYMV (Connecticut strain; Provvidenti et al., 1984), WMV (ATCC PV379), and PRSV-W (ATCC PV380) were propagated in zucchini squash plants (Cucurbita pepo 'Blackjack'; Petoseed Co., Saticoy, Calif.) maintained in a growth chamber (16-h day, constant 26C, irradiance $\left.\approx 300 \mu \mathrm{mol} \cdot \mathrm{m}^{-2} \mathrm{~s}^{-1}\right)$. Cotyledons of 1 -week-old seedlings were lightly dusted with 320-grit Carborundum (Fisher Scientific, Pittsburgh) and mechanically inoculated using sponge plugs. Virus-infected tissue (lyophilized, frozen, or fresh) was macerated in ice-cold $20 \mathrm{~mm}$ sodium phosphate buffer, $\mathrm{pH}$ 7.0, in a prechilled mortar and pestle. All nonbiological materials were sterilized before use. Young, symptomatic, virus-infected leaves were harvested for use as inoculum sources at the time when symptoms were expressed optimally ( 2 to 4 weeks for ZYMV and WMV, 4 to 6 weeks for PRSV-W). Identity and purity of PRSV-W vs. WMV or ZYMV were verified by enzymelinked immunosorbent assay (ELISA) (protocols described below).ZYMV and WMV were differentiated using Phaseolus vulgaris 'Black Turtle 2' (Provvidenti et al., 1984). In this host, WMV elicits prominent, systemic mosaic symptoms in $\approx 2$ to 3 weeks, while ZYMV causes red, necrotic, local lesions on the inoculated leaves.

Cucumber genotypes. The inbred cucumber lines TMG-1, resistant to ZYMV, WMV, and PRSV-W (Provvidenti, 1985), and WI2757, susceptible to all three viruses (Peterson et al., 1982), were provided by Jack Staub
(U.S. Dept. of Agriculture, Univ. of Wisconsin-Madison). The $\mathrm{F}_{1}$ progeny (WI-2757 $\mathrm{x}$ TMG-1) were either self- or sib-pollinated to produce the $\mathrm{F}_{2}$ generation or crossed to parents to produce reciprocal backcross families (WI$2757 \times \mathrm{F}_{1}$ and $\left.\mathrm{F}_{1} \times \mathrm{TMG}-1\right)$. In each cross, the source of resistance came from the male parent. The cultivar Straight 8 (Stokes Seeds, Buffalo, N.Y.) was used as an additional susceptible control genotype.

Experiment designs and data analyses. Plants were mechanically inoculated with virus-infected sap $(\approx 1: 4$ dilution leaf material : buffer) at the cotyledon stage. Rows of susceptible 'Straight 8' plants were evenly spaced throughout each experiment to detect any possible variation in inoculation technique and symptom expression. For the $\mathrm{F}_{2}$ populations, 10 rows of $F_{2}$ individuals with 10 plants per row were interspersed with five internal control rows consisting of inoculated and mockinoculated TMG-1, WI-2757, and $\mathrm{F}_{1}$ plants. Backcross populations consisting of 20 to 120 individuals were arranged similarly ( 10 plants per row along with evenly spaced control rows). The number of times each experiment was performed is included in the table footnotes; experiments termed as independent were performed at different times in the greenhouse. Chi square analyses were performed on data from each experiment individually and on the pooled data from repeated experiments. In each case, there was agreement among all individual experiments and a nonsignificant homogeneity chi square value (see table footnotes). Genetic models proposed are the simplest ones that explained the collective data sets.

Scoring of symptoms. Plants were scored when the symptoms were most clearly expressed. Symptoms of ZYMV and WMV infection generally developed within 7 to 10 days after inoculation; symptoms of PRSV-W infection took 3 to 6 weeks to appear. Susceptibility of an individual plant to virus infection was scored visually, by ELISA, or by both methods. Symptoms caused by cucurbit potyviruses include the presence of mosaic, severe leaf distortion, or rugosity. Symptoms were rated using a scale from 0 to 4 , where 0 $=$ no symptom expression; 1 = light mosaic on at least one leaf; $2=$ moderate mosaic on one or more leaves; $3=$ prominent mosaic on one or more leaves; $4=$ severe mosaic on several leaves, symptoms have spread to terminal leaves, often accompanied by severe stunting. Many experiments were scored by two people; there was agreement to within one point for the ratings given to each plant. When assigning a simple classification of resistant or susceptible, any score of 1 or greater (any symptom expression) was classified as susceptible.

ELISA analyses. Leaves were sampled for virus titer at the time of full symptom expression in the susceptible WI-2757 genotype. For ZYMV and WMV, samples were taken $\approx 3$ weeks after inoculation; for PRSV-W, samples were taken $\approx 6$ weeks after inoculation. One or two young leaves were harvested from each plant, weighed, and stored at $-80 \mathrm{C}$. Ten plants were sampled for each genotype with each 
virus. At least four or more healthy controls were included on each ELISA plate. Healthy and mock-inoculated controls of all the genotypes (TMG-1, WI-2757, their $\mathrm{F}_{1}$ progeny, 'Straight 8', and 'Blackjack' zucchini squash) gave similar readings.

ELISAs were performed using standard sandwich methods (Clark and Adams, 1977); buffers were prepared according to Clark et al. (1986). One leaf per plant was ground in $2 \mathrm{ml}$ of grinding buffer; two 200- $\mu$ l subsamples were assayed for each extract. To adjust for differences in leaf size (and therefore dilution of the leaf sap), absorbance values were divided by the fresh weight of the leaf. ZYMV and WMV were detected with anti-ZYMV (CT strain) polyclonal rabbit IgG antibody (Hammar and Grumet, unpublished) conjugated with alkaline phosphatase (Sigma, St. Louis) as per Clark and Adams (1977). Samples were reacted with p-nitrophenyl phosphatase (Sigma) and absorbance (405 nm) monitored using an EIA Reader model EL-307 (Bio-Tek Instruments, Laboratory Division, Winooski, Vt.). Anti-PRSV-W antibody was purchased from Agdia (Elkhardt, Ind.) and detected by absorbance at $490 \mathrm{~nm}$ using horseradish peroxidase-labeled conjugate and the substrate ophenylenediamine dihydrochloride (OPD; supplied by the Agdia kit).

\section{Results}

When inoculated with PRSV-W, plants of the WI-2757 parent showed mosaic symptoms, while those of the resistant TMG-1 parent and the $F_{1}$ progeny grew vigorously and remained symptom-free (Table 1 ). $\mathrm{The}_{2}$ progeny segregated in a 3:1 [resistant $(\mathrm{R})$ : susceptible $(\mathrm{S})]$ ratio, the WI-2757 $\times \mathrm{F}_{1}$ backcross progeny segregated in a $1: 1(\mathrm{R}: \mathrm{S})$ ratio, and the $\mathrm{F}_{1} \times$ TMG-1 backcross progeny were all resistant. These data support a model in which a single dominant gene in the TMG-1 parent confers resistance to PRSV-W [proposed gene designation, Prsv-2 (to distinguish it from the recessive prsv in 'Surinam Local')]. Full expression of resistance in the $\mathrm{F}_{1}$ progeny depended on optimal growing conditions for the plants, i.e., sunny, warm days ( $\approx 27$ to $30 \mathrm{C}$ ). When grown in cool weather $(\approx 20$ to $25 \mathrm{C})$ or low light levels (i.e., in the growth chamber or during predominantly cloudy days in the greenhouse), the $F_{1}$ progeny sometimes showed very mild symptoms (ratings of 1 vs. 3 to 4 for WI-2757); the TMG-1 parent remained asymptomatic.

The relationship between symptom level and virus level also was examined and compared to the response observed for infection by ZYMV and WMV (Table 2). TMG-1 showed no symptoms (rating of 0 ) for each of the three viruses, while WI-2757 exhibited full symptoms (rating of 4 ) in each case. The $F_{1}$ progeny showed symptoms in response to ZYMV and WMV but not to PRSV-W. These results are consistent with the data presented thus far, and other experiments, which indicate that the resistances to ZYMV and WMV are recessive (Provvidenti, 1985 and Wai and Grumet, 1994, respectively), while resistance to PRSV-W is

Table 1. Segregation data for resistance to PRSV-W in populations derived from the inbred cucumber lines TMG-1 and WI-2757.

\begin{tabular}{|c|c|c|c|c|}
\hline \multirow{2}{*}{$\begin{array}{l}\text { Parent or } \\
\text { progeny }\end{array}$} & \multicolumn{2}{|c|}{ No. plants } & \multirow{2}{*}{$\begin{array}{l}\text { Expected } \\
\text { ratio } \\
(\mathrm{R}: \mathrm{S})^{\mathrm{y}}\end{array}$} & \multirow[b]{2}{*}{$\chi^{2}$} \\
\hline & $\mathrm{R}^{\mathrm{z}}$ & $S$ & & \\
\hline TMG-1 & 58 & 0 & & \\
\hline WI-2757 & 0 & 52 & & \\
\hline$F_{1}$ & 44 & 0 & & \\
\hline $\mathrm{F}_{2}{ }^{\mathrm{x}}$ & 243 & 82 & $3: 1$ & $0.001^{\mathrm{Ns}}$ \\
\hline $\mathrm{F}_{1} \times \mathrm{TMG}-1$ & 75 & 0 & $1: 0$ & \\
\hline WI- $2757 \times \mathrm{F}_{1}{ }^{\mathrm{w}}$ & 130 & 137 & $1: 1$ & $0.13^{\mathrm{Ns}}$ \\
\hline
\end{tabular}

${ }^{2} \mathrm{R}=$ resistant, no symptom expression; $\mathrm{S}=$ susceptible, symptom expression of 1 or greater as described in the Methods section.

${ }^{y}$ Expected ratios based on a single dominant gene model.

${ }^{\mathrm{x}}$ Data pooled from three independent experiments. Each experiment fits the predicted ratios: $\chi_{\exp 1}^{2}=0.003$, $\chi_{\text {exp } 2}^{2}=0.079$, and $\chi_{\text {exp3 }}^{2}=0.003 ; \chi^{2}$ homogeneity $=0.53$, df $=2$.

${ }^{w}$ Data pooled from four independent experiments. Each experiment fits the predicted ratios: $\chi_{\text {exp } 1}^{2}=0.000$, $\chi_{\text {exp2 }}^{2}=0.042, \chi_{\text {exp } 3}^{2}=0.25$, and $\chi_{\text {exp4 }}^{2}=0.008 ; \chi^{2}$ homogeneity $=0.00, \mathrm{df}=3$.

Ns Nonsignificant.

Table 2. Comparison of symptom and enzyme-linked immunosorbent assay (ELISA) data for young, fully expanded leaves of the inbred cucumber lines TMG-1 and WI-2757 and their $\mathrm{F}_{1}$ progeny.

\begin{tabular}{|c|c|c|c|c|c|c|}
\hline \multirow{2}{*}{$\begin{array}{l}\text { Parents or } \\
\text { progeny }\end{array}$} & \multicolumn{2}{|c|}{ ZYMV } & \multicolumn{2}{|c|}{ WMV } & \multicolumn{2}{|c|}{ PRSV-W } \\
\hline & $\overline{\text { Symptom }^{z}}$ & ELISA $^{y}$ & Symptom & ELISA & Symptom & ELISA \\
\hline TMG-1 & $0.0 \pm 0.0^{x}$ & $0.028 \pm 0.003$ & $0.0 \pm 0.0$ & $0.022 \pm 0.055$ & $0.0 \pm 0.0$ & $1.081 \pm 0.324$ \\
\hline WI-2757 & 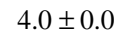 & $0.582 \pm$ & .0 & $1.150 \pm$ & \pm 0.0 & $1.361 \pm 0.312$ \\
\hline $\mathrm{F}_{1}$ & $3.0 \pm 0.0$ & $0.322 \pm 0.048$ & $3.3 \pm 0.1$ & $0.271 \pm 0.033$ & $0.0 \pm 0.0$ & $1.320 \pm 0.359$ \\
\hline $\begin{array}{l}\text { Mock- } \\
\text { inoculated }\end{array}$ & $0.0 \pm 0.0$ & $0.028 \pm 0.003$ & $0.0 \pm 0.0$ & $0.015 \pm 0.003$ & $0.0 \pm 0.0$ & $0.010 \pm 0.049$ \\
\hline
\end{tabular}

${ }^{2}$ Symptom ratings were on a 0 to 4 scale where $0=$ none and $4=$ severe.

yYoung, fully expanded leaves were ground in $2 \mathrm{ml}$ of virus buffer. Adjusted ELISA values were calculated by dividing the absorbance value by the fresh weight of each leaf.

${ }^{\mathrm{x}}$ Each value is the mean of 10 replicate plants $\pm \mathrm{SE}$ (standard error).

"Mock-inoculated controls are an average of TMG-1, WI-2757, $\mathrm{F}_{1}$, and 'Straight 8 ' genotypes. There were no differences among genotypes for control ELISA values.

dominant (Table 1). However, when virus titers were examined, a different pattern was observed. As might be expected, high virus titers were detected in the susceptible WI2757 for all three viruses and for ZYMV and WMV in the symptomatic $F_{1}$ progeny. Little or no ZYMV and WMV were detected in young leaves in the resistant TMG-1 plants. Conversely, high levels of PRSV-W were found in young leaves in both the TMG- 1 and $\mathrm{F}_{1}$ genotypes, despite an absence of symptoms.

\section{Discussion}

We have examined the inheritance of resistance to PRSV-W in the TMG-1 cucumber line. Segregation data suggest that resistance to PRSV-W was due to a single dominant gene (Prsv-2). In each case, the severity of symptoms for the parental and $\mathrm{F}_{1}$ progeny fell within very narrow ranges (i.e., strong symptoms in the susceptible genotypes and none in the resistant genotypes; Table 2). The segregating $\mathrm{F}_{2}$ populations, however, exhibited a broader range of symptom expression. In each population, there was a clear class of individuals without symptoms. For those with symptoms, however, different degrees of susceptibility were observed (ratings ranged from 1 to 4), suggesting the action of modifying factors in the absence of the major resistance gene. Similar results were reported by Cohen et al. (1971) with regard to symptom expression among segregating populations derived from the WMV-resistant cucumber cultivar Kyoto 3 Feet Long, and by other investigators for a variety of viruses and species (Kyle, 1993).

The gene for resistance to PRSV-W in TMG-1 is not likely to be the same as one of the genes conferring resistance to ZYMV or WMV. Both the mode of inheritance [dominant for PRSV-W vs. recessive for ZYMV and WMV (Provvidenti, 1985, 1987; Wai and Grumet, 1995)] and the mechanism of resistance appear to be different. Little or no virus was detected in the upper leaves of TMG-1 inoculated with ZYMV or WMV. However, when inoculated with PRSV-W, virus levels similar to those found in the susceptible WI-2757 parent were observed in the upper leaves of the asymptomatic TMG-1 parent and $F_{1}$ progeny. It may be more appropriate to describe the resistance to PRSV in TMG-1 as tolerance. Interestingly, 'Kyoto 3 Feet Long' plants, which possess a dominant gene for WMV resistance, also accumulate virus despite a lack of symptoms (Cohen et al., 1971).

The resistance to PRSV-W in TMG-1 can be contrasted with that found in the cucumber cultivar Surinam Local. The resistance to PRSV-W in TMG-1 was dominant, whereas the resistance in 'Surinam Local' was recessive (Wang et al., 1984). The resistance in 'Surinam Local' appears to act at the level of movement, since virus was detected by symptom and ELISA on the first few leaves but not in upper leaves. In contrast, TMG- 1 shows no symptoms of PRSV-W, but has high virus titers in the upper leaves. It appears that both the genetics and mechanism of resistance differ between TMG-1 and 'Surinam Local'. Whether the allele for resistance to PRSV-W 


\section{Breeding, Cultivars, Rootstocks, \& Germplasm Resources}

in TMG-1 is at the same locus as is the resistance allele in 'Surinam Local' remains to be determined.

\section{Literature Cited}

Clark, M.F. and A.N. Adams. 1977. Characteristics of the microplate method of enzyme-linked immunosorbent assay for the detection of plant viruses. J. Gen. Virol. 34:475-483.

Clark, M.F., R.M. Lister, and M. Bar-Joseph. 1986. ELISA techniques. Methods Enzymol. 118:742780.

Cohen, S., E. Gertman, and N. Kedar. 1971. Inheritance of resistance to melon mosaic virus in cucumbers. Phytopathology 61:253255.

Davis, R.F. and M.K. Mizuki. 1985. Detection of cucurbit viruses in New Jersey. Plant Dis. 71:4044.

Kyle, M.M. 1993. Resistance to viral diseases of vegetables: Genetics and breeding. Timber Press, Portland, Ore.

Nameth, S.T., J.A. Dodds, A.O. Paulus, and F.F. Laemmlen. 1986. Cucurbit viruses of California: An ever changing problem. Plant Dis. 70:8 11.

Nameth, S.T., F.F. Laemmlen, and J.A. Dodds. 1985. Viruses cause heavy melon losses in desert valleys. Calif. Agr. July-August:28-29.

Peterson, C.E., P.H. Williams, M. Palmer, and P. Louward. 1982. Wisconsin 2757 cucumber. HortScience 17:268

Provvidenti, R. 1985. Sources of resistance to viruses in two accessions of Cucumis sativus. Cucurbit Gen. Coop. Rpt. 8:12.

Provvidenti, R. 1987. Inheritance of resistance to a strain of zucchini yellow mosaic virus in cucumber. HortScience 22:102-103.

Provvidenti, R., D. Gonsalves, and H.S. Humaydan. 1984. Occurrence of zucchini yellow mosaic virus in cucurbits from Connecticut, New York,
Florida and California. Plant Dis. 68:443-446.

Purcifull,D. and D. Gonsalves. 1984. Papaya ringspot virus. Commonwealth Mycological Institute/ Association of Applied Biologists (eds.). Descriptions of plant viruses 292. Kew, Surrey, England.

Sammons, B., O.W. Barnett, R.F. Davis, and M.K. Mizuki. 1989. A survey of viruses infecting yellow summer squash in South Carolina. Plant Dis. 73:401-404.

Wai, T. and R. Grumet. 1995. Inheritance of resistance to watermelon mosaic virus in the cucumber line TMG-1: Tissue-specific expression and relationship to zucchini yellow mosaic virus resistance. Theor. Appl. Genet. (In press.)

Wang, Y.J., R. Provvidenti, and R.W. Robinson. 1984. Inheritance of resistance to watermelon mosaic virus 1 in cucumber. HortScience 19:587588.

Wehner, T.C. 1993. Gene list update for cucumber. Cucurbit Gen. Coop. Rpt. 16:92-95. 